\title{
A ANTROPOLOGIA JURÍDICA DE MARX E ENGLS
}

Tradução de: Lucas Parreira Álvares

\begin{abstract}
Graduado em Ciências do Estado pela Universidade Federal de Minas Gerais, Mestrando em Direito pela Universidade Federal de Minas Gerais e Graduando em Ciências Sociais pela Universidade Federal de Minas Gerais-
\end{abstract}

UFMG

Recebimento: 30/03/2018

Aprovação: 11/09/2018

\section{Como citar esta tradução:}

A antropologia jurídica de Marx e Engels. Tradução de ÁLVARES, Lucas Parreira. In: Revice - Revista de Ciências do Estado, Belo Horizonte, v.3, n.2, p. 94-96, jun./dez.2018. ISSN 2525-8036. Título original: L'antropologie juridique de Marx et Engels, Norbert Rouland

A reutilização pelos fundadores do marxismo das conclusões de Morgan foi tanto uma oportunidade como um infortúnio para este autor: por um lado, a curto prazo, contribuiu para a sua difusão; mas, a longo prazo, provocou o descrédito - exagerado em certos pontos - em que sua obra acabou caindo, pois, muitas vezes, através de Morgan, é o marxismo que se ataca.

F. Engels (1820-1895) é mais um historiador do que um etnólogo. Ele pretende retornar para a origem das instituições, as quais ele identifica com as sociedades primitivas, para determinar o significado da história, enfocando o conceito de luta de classes. Na Origem da Família, da Propriedade privada e do Estado (1884), ele retoma a tese de Morgan: a família conjugal moderna nasceu da reabsorção gradual da comunidade conjugal arcaica excluindo parentes, com exceção do pai e da mãe.

As observações científicas posteriores desmentiram essas afirmações. Mesmo em sociedades que não vinculam sexo com filiação, a família conjugal ainda possui algum grau de existência. Além disso, a história comparativa mais recente da família leva à rejeição da unilinearidade da evolução: a família extensa não representa necessariamente um estágio anterior à família restrita, sendo que o processo inverso também pode ser observado.

Há, no entanto, outros pontos em que a antropologia jurídica de Marx e Engels anuncia a época presente. Por um lado, na linhagem [p. 53] de Montesquieu, esses autores rejeitam as concepções da lei natural clássica e afirmam que o conteúdo do direito, como um produto histórico da vida socioeconômica, é fundamentalmente variável, uma vez que este pertencente às superestruturas, e que estas mudam de acordo com as variações das condições materiais. Por outro 
lado, abordam diretamente um dos problemas cruciais da antropologia jurídica: o vínculo entre lei e estado. Para eles, o estado é uma forma transitória de organização do poder: nem sempre existiu, e desaparecerá um dia. O estado é, de fato, apenas uma variante de uma noção mais ampla, a de autoridade pública. Esta consiste na existência de um aparelho que garanta a eficácia da observância pelos indivíduos dos princípios que permitem que a sociedade funcione. Mas ela pode se conformar de forma diferente. Quando a autoridade pública reflete a vontade de apenas uma fração da sociedade (ou os grupos dirigentes), quando as forças armadas em que ela se apoia estão apartadas da população e constituem uma polícia ou um exército, então estamos diante de um estado. Por outro lado, quando a sociedade não está dividida, estamos diante de uma sociedade tradicional.

Para Marx e Engels, a lei pode existir sem o estado, mas estará ligada à presença de uma autoridade pública. Ora, nem toda sociedade não estatal possui necessariamente uma autoridade pública. Nossos autores localizam precisamente sua aparição, a partir do esquema evolucionista de Morgan, na primeira etapa do segundo estágio (Barbárie), e somente em certas sociedades (como os Iroqueses). Então, se a lei é um fenômeno geral, ela não é universal: ao longo da primeira etapa de sua evolução - que durou centenas de milhares de anos - a humanidade viveu sem direitos e conhecerá o futuro das sociedades sem classes onde a lei, substituída pela moralidade, desaparecerá novamente.

É certamente fácil - e os autores opostos não se privaram - culpar o marxismo sobre este último ponto: desde a morte de nossos autores, nada anuncia o desaparecimento dos Estados, não mais do que o da lei.

No entanto, a abordagem de Marx e Engels parece-nos decisiva para a história da antropologia jurídica por vários pontos de vista.

Antes de qualquer coisa, ela prefigura alguns dos nossos mais importantes debates atuais. Em primeiro lugar, sobre o vínculo entre lei e estado, no qual eles orientam a problemática na direção correta, que é a da diferença de natureza entre esses dois conceitos. Outro debate fundamental, o de identificar o direito com normas ou [p. 54] processos. Marx e Engels não dizem que a lei deve consistir necessariamente em regras explícitas e codificadas, formalmente sancionadas por um poder executivo, e admitem que o costume, por obedecer a regras diferentes, não deixa de ser lei. Então, ainda que ela o faça no âmbito extremamente rígido do evolucionismo unilinear, sua teoria inscreve em um contínuo a existência, por um lado, da lei, por outro lado, do Estado, inscrição que estabelece a variabilidade cultural da lei. Além disso, contribui para uma descentralização da pesquisa especificamente de natureza antropológica. Embora seja verdade que Marx se preocupou principalmente com as sociedades ocidentais, não é menos verdade que, em seu texto sobre as 
Formas que precedem a produção capitalista (1857-1858) este autor estudou formações socioeconômicas exóticas, particularmente pela definição do modo de produção asiático.

Se Morgan, Marx e Engels pecam por se manterem ao lado do evolucionismo, é preciso lembrar que essa doutrina era dominante na época. Foi a primeira das grandes escolhas teóricas da antropologia jurídica, que devemos agora estudar, recordando que, apesar dos erros de interpretação, esse período de apenas vinte anos (1860-1880) foi de excepcional riqueza para nossa disciplina. A reflexão sobre a lei começa a se libertar dos modelos romanistas e civilistas; não só sociedades exóticas, mas também sociedades europeias, em suas formas passadas, são definidas como objetos da antropologia jurídica; esta, nas suas primeiras explorações, contribui para a descoberta das duas áreas que serão, durante um século, os principais campos experimentais da antropologia social e cultural: o parentesco e a mitologia. 